\title{
PENGARUH KUALITAS PELAYANAN CUSTOMER SERVICE TERHADAP KEPUASAN NASABAH PADA BANK BJB KCP CIPANAS
}

\author{
Reksa Jayengsari $^{1}$, Rani Yunita ${ }^{2}$, Sri Maloka ${ }^{3}$
}

${ }^{1,2,3}$ Fakultas Ekonomi dan Bisnis Islam,Universitas Suryakancana reksaecha22@gmail.com, raniyunita999@gmail.com, srimaloka@gmail.com

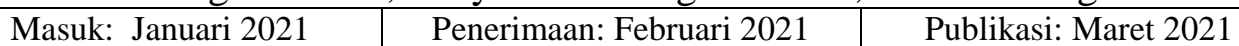

\begin{abstract}
ABSTRAK
Kualitas pelayanan adalah totalitas fitur dan karakteristik produk atau jasa yang tergantung pada kemampuannya untuk memuaskan kebutuhan yang dinyatakan atau tersirat. Kepuasan pelanggan adalah tingkat perasaan seseorang setelah membandingkan kinerja (atau hasil) yang ia persepsikan dibandingkan dengan harapannya. Penelitian ini bertujuan untuk menganalisis kualitas pelayanan Customer Serviceterhadap kepuasan nasabah dan menguji pengaruh kualitas pelayanan Customer Service terhadap kepuasan nasabah pada Bank BJB KCP Cipanas. Penulis menggunakan pendekatan kuantitatif dengan metode analisis deskriptif dan analisis statistik. Populasi pada penelitian iniJ yaitu sekuruh nasabah Bank BJB KCP Cipanas, dengan jumlah sampel yang diambil sebanyak 100 orang. Sedangkan alat pengumpulan data yang digunakan adalah kuesioner. Hasil analisis penelitian menunjukkan pengaruh kualitas pelayanan Customer Service terhadap kepuasan nasabah pada Bank BJB KCP Cipanas.
\end{abstract}

Kata kunci: Kualitas, Pelayanan, Kepuasan

\section{ABSTRACT}

Service quality is the totality of features and characteristics of a product or service that depends on its ability to satisfy stated or implied needs. Customer satisfaction is the level of a person's feelings after comparing the performance (or results) he perceives compared to his expectations. This study aims to analyze the quality of Customer Serviceon customer satisfaction and to examine the effect of Customer Servicequality on customer satisfaction at Bank BJB KCP Cipanas. The author uses a quantitative approach with descriptive analysis methods and statistical analysis. The population in this study were all customers at Bank BJB KCP Cipanas, with a total sample of 100 people. Meanwhile, the data collection tool used was a questionnaire. The results of the research analysis showed the influence of Customer Servicequality on customer satisfaction at Bank BJB KCP Cipanas.

Keyword: quality, service, satisfaction

\section{A. PENDAHULUAN}

Dunia perbankan saat ini mengalami perkembangan yang sangat pesat, sehingga keadaan ini menimbulkan bisnis perbankan yang kompetitif dan persaingan yang ketat. Globalisasi dalam bidang perbankan saat ini berpengaruh besar terhadap persaingan. Perusahaan yang mempunyai keunggulan dalam 
bersaing akan menjadi kunci sukses dalam persaingan yang semakin ketat seperti sekarang ini. Hal ini harus dilakukan oleh setiap perusahaan karena hanya dengan langkah inilah kelangsungan perusahaan akan dapat terjaga.

Dalam industri jasa, kualitas pelayanan adalah faktor yang sangat penting karena merupakan suatu Profit Strategy untuk memikat lebih banyak pelanggan baru, mempertahankan pelanggan yang ada, menghindari berpindahnya pelanggan dan menciptakan keunggulan khusus. Kepuasan pelanggan tidak hanya mendukung bertahannya suatu perusahaan, tetapi juga bagaimana perusahaan tersebut berkembang. Pelayanan harus dilakukan terus menerus tanpa henti, karena bank bekerja berdasarkan prinsip kepercayaan, sehingga value itu menjadi penting. Value terbaik bisa membuat nasabah puas dan pada akhirnya nasabah menjadi loyal (Supriyanto, 2003).(Syahputra \& Susianto, 2020)

Selain itu, setiap perusahaan perbankan harus selalu melakukan inovasi baik dalam hal pelayanan sehingga akan lebih diminati oleh nasabah. Kepuasan dan ketidakpuasan nasabah adalah hasil penilaian nasabah terhadap apa yang diharapkannya dengan membeli dan menggunakan produk atau jasa bank. Jika nasabah merasa puas, maka nasabah akan kembali menggunakan jasa perusahaan dan menjadi pelanggan yang setia serta akan menceritakan pengalamannya tersebut kepada orang lain, bahkan memberi rekomendasi kepada orang lain untuk menggunakan jasa di perusahaan tersebut. Sebaliknya jika nasabah merasa tidak puas, maka nasabah tersebut juga akan menceritakan pelayanan yang mengecewakan tersebut kepada orang lain, sehingga akan memperburuk citra dan eksistensi perusahaan yang akan berakibat menurunnya jumlah pemakai jasa perusahaan (Husaeni, 2017).

Salah satu tolak ukur keberhasilan bank dapat dicapai apabila bank memiliki jumlah nasabah yang banyak karena yang menggunakan dananya adalah nasabah. Saat ini, para bank berusaha keras untuk memenuhi kebutuhan dan keinginan nasabah dengan menawarkan berbagai jenis produknya. Semua ini menjadi bagian penting dalam mendorong setiap bank menempatkan orientasinya pada kepuasan nasabah sebagai tujuan utamanya. Para bank pun semakin yakin bahwa kunci sukses untuk memenangkan persaingan terletak pada kemampuannya memberikan 
Total Customer Value yang dapat memuaskan nasabah melalui pelayanan yang diberikan pihak bank.

Menurut Kotler (2009: 83) bahwa kualitas pelayanan merupakan totalitas fitur dan karakteristik produk atau jasa yang tergantung pada kemampuannya untuk memuaskan kebutuhan yang dinyatakan atau tersirat. Ini jelas merupakan definisi kualitas yang berpusat pada konsumen, seorang produsen dapat memberikan kualitas bila produk atau pelayanan yang diberikan dapat memenuhi atau melebihi harapan konsumen.(Hamdani, 2019)

Kualitas pelayanan terhadap nasabah menjadi salah satu hal yang sangat urgen untuk diperhatikan oleh bank-bank yang beroperasi. Pelayanan yang baik dan paripurna penting untuk memberikan kepuasan kepada nasabah. Pelayanan bank yang baik juga akan memberikan kenyamanan buat nasabah selain itu akan membuat nasabah akan semakin loyal terhadap bank, selain itu akan menambah keparcayaan (trust) kepada bank.

Customer Service adalah jantungnya perusahaan terutama pada perbankan. Mereka membantu perbankan menjadi berkembang dengan selalu memenuhi kebutuhan pelanggan.Customer Service bertugas melayani, memberikan informasi tentang produk-produk bank dan fasilitas apa saja yang dapat dimiliki oleh nasabah.

Perusahaan pelayanan jasa seperti perbankan, dituntut lebih memaksimalkan performa kualitas pelayanan yang dilakukan oleh customer service. Bagi perusahaan yang menawarkan jasa tentu cukup sulit untuk mendapatkan standart pelayanan yang sama dimata konsumen dalam memberikan pelayanan, bank harus mewajibkan seluruh karyawan dan seluruh personal yang terdapat di dalamnya untuk memberikan pelayanan yang terbaik dan semaksimal mungkin, khususnya pelayanan yang dilakukan Customer Service dikarenakan Customer Service adalah orang yang lebih banyak menerima keluhan-keluhan dari nasabah serta compalain dari nasabah. Serta menjalin hubungan silahturahim yang baik. Selain itu, Customer Service juga yang selalu berinteraksi terhadap para nasabah terutama mengenai produk perbankan. Jadi, Customer Service harus bisa memberikan pelayanan yang terbaik dan semaksimal mungkin, agar nasabah merasa puas atas pelayanan yang diberikan dan lebih loyal lagi terhadap bank tersebut.(Marlius \& Putriani, 2020) 
Menurut Kotler, et al, dalam Fandy Tjiptono (2017: 287) Kepuasan pelanggan adalah tingkat perasaan seseorang setelah membandingkan kinerja (atau hasil) yang ia persepsikan dibandingkan dengan harapannya. Hal ini dapat berarti jika kinerja dibawah harapan, nasabah akan merasa tidak puas. Jika kinerja sama dengan harapan, nasabah merasa puas, dan jika kinerja melampaui harapan, nasabah akan sangat puas atau bahagia. Nasabah yang merasa puas, akan selalu memberikan komentar yang baik tentang perusahaan dan cenderung akan setia lebih lama pada perusahaan.

Berdasarkan hasil observasi dan wawancara awal peneliti kepada para nasabah di dapat informasi bahwa terdapat ketidakpuasan nasabah terhadap kecepatan layanan Customer Service di Bank BJB KCP Cipanas. Jadi, jika pihak perbankan mengharapakan loyalitas dari nasabah, mereka harus mampu dan mau memanjakan konsumen atau nasabahnya. Kalau tidak maka perbankan harus siapsiap ditinggalkan oleh nasabahnya di tengah ketatnya persaingan industri perbankan, tidak terkecuali perbankan syariah yang sudah mulai bergeliat, seiring adanya regulasi di bidang perbankan yang sangat dinamis (Bank Indonesia, 1998). Tapi ironisnya berdasarkan fenomena sekarang ini ternyata masih banyak bank yang masih mengabaikan pelayanan yang baik kepada nasabah, kondisi ini sudah menjadi rahasia umum terkait pelayanan bank di Indonesia. Kondisi ini banyak diungkapkan nasabah yang mengeluhkan pelayanan bank berdasarkan pengalaman yang dialami, tentang buruknya pelayanan bank, baik itu bank konvensional maupun bank yang berbasis syariah (Marzuki, 2016).

Padahal sejatinya kesuksesan perusahaan termasuk perbankan dalam memberikan pelayanan yang maksimal atau service quality. Adalah seberapa jauh antara harapan dan kenyataan yang diterima oleh pelanggan atau nasabah. Apakah harapan mereka sudah sesuai dengan kenyataan yang diharapakan (Adiwarman Karim dalam Mustagfiroh, 2016).

Bank BJB sadar betul bahwa kualitas pelayanan memiliki peran penting dalam menciptakan kepuasan nasabah. Nasabah yang semakin kritis terhadap pelayanan yang diperoleh membuat Bank BJB KCP Cipanas harus dapat melaksanakan kegiatan operasional sebaik mungkin untuk memberikan pelayanan yang terbaik. Peningkatan dan penurunan jumlah nasabah dari tahun ke tahun dapat 
dijadikan evaluasi bagi perusahaan untuk menilai seberapa tinggi kepuasan nasabah pada pelayanan yang diberikan perusahaan. Berdasarkan latar belakang tersebut maka diperoleh perumusan masalah dalam penelitian ini yaitu tentang pengaruh kualitas pelayanan Customer Service terhadap kepuasan nasabah di Bank BJB KCP Cipanas.(Mulyaningsih \& Suasana, 2016)

Dengan demikian tujuan penelitian ini adalah untuk mengetahui seberapa besar pengaruh kualitas pelayanan Customer Service terhadap kepuasan nasabah di Bank BJB KCP Cipanas. Penelitian ini diharapkan akan bermanfaat untuk pengembangan industri perbankan syariah di Indonesia secara umum. Kemudian dampak terhadap keilmuan adalah bisa menjadi referensi buat peneliti selanjutnya ataupun penelitian-penelitian sejenis, khusunya dalam kaidah keilmuan kontemporer dalam rangka era kebangkitan perbankan syariah di Indonesia dan di negara-negara yang mayoritas berpenduduk muslim di dunia seperti Malaysia dan negara-negara Arab di Timur Tengah.(Subagja \& Hanifah, 2020)

\section{B. KERANGKA TEORI}

\section{Kualitas Pelayanan}

Hasil studi menunjukkan bahwa ada beberapa indikator yang menjadi kualitas pelayanan, hal ini seperti yang diungkapkan Parasuraman, dkk (dalam Prastiwi, dkk Yogyakarta, 2017) yang mengatakan bahwa ada sepuluh dimensi pokok kualitas pelayanan, yakni reliabilitas, responsivitas atau daya tanggap, kompetensi, akses, kesopanan, komunikasi, kredibilitas, keamanan, kemampuan memahami pelanggan, bukti fisik, meliputi penampilan fasilitas fisk, peralatan, personel, dan bahan-bahan komunikasi perusahaan (misalnya, kartu bisnis, kop surat, dan lain-lain). (Guspul, 2014)

Selanjutnya kualitas pelayanan dapat dimaknai sebagai sejauhmana perbedaan terhadap layanan yang diharapkan oleh nasabah atau pelanggan yang mereka terima, hal ini baru dapat diketahui dengan membandingkan persepsi nasabah terhadap layanan yang mereka peroleh. (Febriana, 2016).

Setidaknya ada lima dimensi pelayanan yang wajib dipenuhi oleh perusahaan dalam melayani pelanggan yang disebut Service Quality (SERVQUAL), yaitu: bukti langsung, kehandalan, daya tanggap, empati, dan 
jaminan. (Ratmino dan Atik dalam Febriana, 2016). Dari beberapa pengertian di atas, maka dapat disimpulkan bahwa kualitas pelayanan adalah harapan dan kenyataan menjadi indikator penting terhadap kepuasan nasabah. Nasabah tentu berharap banyak pelayanan yang diberikan akan bisa memenuhi harapan mereka, sehingga mereka akan terpuaskan dan akan semakin loyal.

\section{Kepuasan Nasabah}

Kepuasan nasabah menjadi fokus perhatian dari bank-bank yang beroperasi, hal ini karena bank menyadari tentang pentingnya nasabah terhadap kemajuan bisnis mereka. Karena sebuah bank tanpa nasabah tentu akan berdampak terhadap usaha perbankan itu sendiri. Oleh sebab itu, persaingan antar bank sangatlah tinggi dalam memperebutkan calon nasabah baru supaya tertarik menjadi nasabah mereka. Sehingga apapun caranya selama masih layak dilakukan akan mereka perbuat demi pengembangan usaha. Adapun tentang kepuasan nasabah menurut Tse dan Wilton (dalam Prasetyo, 2012) disebutkan bahwa kepuasan nasabah merupakan respon dari nasabah terhadap evaluasi ketidaksesuaian yang dirasakan setelah pemakaiannya.(Saputra \& Alwie, 2015)

Selanjutnya dikatakan bahwa kepuasan nasabah merupakan harapan dari perusahaan terhadap tingkat keunggulan yang diberikan kepada nasabah dan pengendalian atas tingkat keunggulan tersebut untuk memenuhi harapan nasabah (Lovelock dalam Mutaqin, 2006).

Selanjutnya Cahyani (2016) mendefinisikan bahwa faktor-faktor kualitas jasa yang mempunyai andil terbesar sampai terkecil dalam memberikan kepuasan pada nasabah yaitu responsiveness, compliance, emphaty, tangible, reliabity dan assurance.

\section{METODE PENELITIAN}

Penelitian ini merupakan penelitian kuantitatif, karena metode yang digunakan untuk mengumpulkan atau mencari data dalam penelitian ini berbentuk presentase yang menggunakan angka. Instrumen yang digunakan dalam pengumpulan data penelitian ini adalah dengan penyebaran kuesioner kepada 
nasabah Bank BJB KCP Cipanas sebagai objek penelitian. Populasi dalam penelitian ini adalah seluruh nasabah Bank BJB KCP Cipanas. Pengambilan sampel dalam penelitian ini dilakukan dengan menggunakan Incidental Sampling (Sampling Insidental). Sampling insidental adalah teknik penentuan sampel berdasarkan kebetulan, yaitu siapa saja yang secara kebetulan/incidental bertemu dengan peneliti dapat digunakan sebagai sampel, bila dipandang orang yang kebetulan ditemui itu cocok sebagai sumber data. (Saputra \& Alwie, 2015)

Sampel yang diteliti berjumlah 100 orang nasabah. Adapun teknik pengumpulan data yang digunakan dalam penelitian adalah dengan cara penyebaran kuesioner. Kuesioner yang diberikan kepada nasabah untuk mengetahui kenyataan yang terjadi di lapangan. Kuesioner tersebut berkaitan dengan kualitas pelayanan Customer Service di Bank BJB KCP Cipanas.

Identifikasi variabel dalam penelitian ini adalah sebagai berikut.

a. Variabel bebas (X) adalah kualitas pelayanan Customer Service yang terdiri dari indikator-indikator tangibles (bukti fisik), reliability (keandalan), responsiveness (daya tanggap), assurance (jaminan), dan empathy (empati). b. Variabel terikat (Y) adalah kepuasan nasabah Bank BJB KCP Cipanas.

Analisis data yang digunakan dalam penelitian ini adalah analisis regresi sederhana (simple regression analysis) dengan bantuan aplikasi SPSS. Analisis regresi sederhana digunakan untuk menganalisis pengaruh kualitas pelayanan Customer Service sebagai X yang terdiri dari indikator-indikator tangibles (bukti fisik), reliability (keandalan), responsiveness (daya tanggap), assurance (jaminan), dan empathy (empati) terhadap kepuasan nasabah Bank BJB KCP Cipanas sebagai Y.

Persamaan regresi linear sederhana dalam penelitian ini adalah:

$$
\mathbf{Y}=\mathbf{a}+\mathbf{b} \mathbf{X}
$$

Dimana:

Y = Variabel Response (Dependent), yaitu kepuasan nasabah

$\mathrm{X}=$ Variabel Predictor (Independent), yaitu kualitas pelayanan CS

a $\quad=$ Konstanta

$\mathrm{b} \quad=$ Koefisien regresi (kemiringan); besaran Response yang ditimbulkan oleh

\section{Predictor}




\section{HASIL DAN PEMBAHASAN}

\section{Karakteristik Responden Berdasarkan Usia}

Berdasarkan data yang terkumpul dari 100 orang nasabah sebagai sampel dalam penelitian ini diperoleh informasi mengenai usia mereka yang disajikan dalam tabel berikut.

Tabel 1. Karakteristik Responden Berdasarkan Usia

\begin{tabular}{cccc}
\hline No. & Usia (Tahun) & Jumlah (Orang) & Presentase (\%) \\
\hline 1 & $<20$ & 9 & 9,00 \\
\hline 2 & $20-30$ & 46 & 46,00 \\
\hline 3 & $31-40$ & 19 & 19,00 \\
\hline 4 & $41-50$ & 15 & 15,00 \\
\hline 5 & $>50$ & 11 & 11,00 \\
\hline & Jumlah & $\mathbf{1 0 0}$ & $\mathbf{1 0 0 , 0 0}$ \\
\hline
\end{tabular}

Dari tabel 1 diatas dapat dilihat bahwa usia nasabah yang menggunakan Bank BJB KCP Cipanas sangat bervariasi, mulai dari usia kurang dari 20 tahun sampai dengan usia lebih dari 50 tahun. Dalam tabel juga kita dapat menyimpulkan bahwa usia responden yang dominan adalah pada usia 20 - 30 tahun, yaitu $46 \%$. Sedangkan usia responden yang paling sedikit menggunakan jasa Bank BJB KCP Cipanas adalah pada usia kurang dari 20 tahun, yaitu $9 \%$.

\section{Karakteristik Responden Berdasarkan Jenis Kelamin}

Berdasarkan data yang terkumpul dari 100 orang nasabah sebagai sampel dalam penelitian ini diperoleh informasi mengenai jenis kelamin mereka yang disajikan dalam tabel berikut.

Tabel 2. Karakteristik Responden Berdasarkan Jenis Kelamin

\begin{tabular}{cccr}
\hline No. & Jenis Kelamin & Jumlah (Orang) & Presentase (\%) \\
\hline 1 & Laki-laki & 35 & 35,00 \\
\hline 2 & Perempuan & 65 & 65,00 \\
\hline & Jumlah & $\mathbf{1 0 0}$ & $\mathbf{1 0 0 , 0 0}$ \\
\hline
\end{tabular}

Dari tabel 2 di atas dapat dilihat bahwa responden yang berjenis kelamin laki-laki berjumlah 35 orang $(35 \%)$ dan responden yang berjenis kelamin perempuan berjumlah 65 orang (65\%). Ini artinya, responden yang berjenis kelamin perempuan lebih dominan dibandingkan responden yang berjenis kelamin laki-laki.

\section{Karakteristik Responden Berdasarkan Pendidikan Terakhir}


Berdasarkan data yang terkumpul dari 100 orang nasabah sebagai sampel dalam penelitian ini diperoleh informasi mengenai pendidikan terakhir mereka yang disajikan dalam tabel berikut.

Tabel 3. Karakteristik Responden Berdasarkan Pendidikan Terakhir

\begin{tabular}{cccr}
\hline No. & Jenis Kelamin & Jumlah (Orang) & Presentase (\%) \\
\hline 1 & SMA/SMK/MA/Sederajat & 63 & 63,00 \\
\hline 2 & S1 & 32 & 32,00 \\
\hline 3 & S2 & 5 & 5,00 \\
\hline & Jumlah & $\mathbf{1 0 0}$ & $\mathbf{1 0 0 , 0 0}$ \\
\hline
\end{tabular}

Dari tabel 3 di atas dapat disimpulkan bahwa para nasabah yang menjadi responden dalam penelitian ini dominan berpendidikan terakhir SMA/SMK/MA/Sederajat, yaitu sebanyak 63 orang (63\%).

\section{Karakteristik Responden Berdasarkan Pekerjaan}

Berdasarkan data yang terkumpul dari 100 orang nasabah sebagai sampel dalam penelitian ini diperoleh informasi mengenai pekerjaan mereka yang disajikan dalam tabel berikut.

Tabel 4. Karakteristik Responden Berdasarkan Pekerjaan

\begin{tabular}{clcr}
\hline No. & \multicolumn{1}{c}{ Pekerjaan } & Jumlah (Orang) & Presentase (\%) \\
\hline 1 & PNS/ASN & 6 & 6,00 \\
\hline 2 & Karyawan Swasta & 15 & 15,00 \\
\hline 3 & Guru & 30 & 30,00 \\
\hline 4 & Wiraswasta/Wirausaha & 11 & 11,00 \\
\hline 5 & Mahasiswa/Pelajar & 12 & 12,00 \\
\hline 6 & Ibu Rumah Tangga & 13 & 13,00 \\
\hline 7 & Belum Bekerja/Tidak Disebutkan & 13 & 13,00 \\
\hline & Jumlah & $\mathbf{1 0 0}$ & $\mathbf{1 0 0 , 0 0}$ \\
\hline
\end{tabular}

Dari tabel 4 di atas dapat dilihat bahwa responden dominan bekerja sebagai guru, yaitu sebanyak 30 orang (30\%). Kemudian disusul dengan pekerjaan responden sebagai karyawan swasta, yaitu sebanyak 15 orang (15\%). Sedangkan untuk jumlah responden dengan pekerjaan paling sedikit adalah PNS/ASN, yaitu sebanyak 6 orang saja $(6 \%)$.

\section{Validitas dan Reabilitas}

Penilaian uji validitas adalah dengan mengkolerasikan antara skor butir dengan skor total, bila kolerasi tiap faktor tersebut positif dan $\mathrm{r}$ lebih besar atau sama dengan 0,30, maka instrument dinyatakan valid dengan tingkat signifikan (alpha) 5\% (0,05) (Sugiyono, 2010:172). Jika kita melihat daftar r tabel untuk 
banyak responden 100 orang dengan tingkat signifikan 0,05, dapat diketahui bahwa nilai $\mathrm{r}$ tabelnya $=0.1966$. Dari hasil uji validitas di atas, dapat dilihat bahwa $\mathrm{r}$ hitung $>\mathrm{r}$ tabel atau dapat juga dilihat dari segi $\mathrm{r}$ hitung $>0,30$, maka dapat disimpulkan bahwa seluruh indikator dalam angket ini valid. Berdasarkan hasil uji validitas didapat seluruh item pernyataan dinyatakan valid, hasil signifikasi tiap-tiap item pernyataan dibawah 0,05 .

\begin{tabular}{r|r}
\hline \multicolumn{2}{c}{ Reliability Statistics } \\
Cronbach's Alpha & N of Items \\
\hline .951 & 20 \\
\hline
\end{tabular}

Reliabilitas merupakan derajat konsistensi dan stabilitas data atau temuan penelitian yang ditunjukkan oleh instrumen pengukur dimana pengujiannya dilakukan secara internal, yaitu pengujian dengan menganalisis konsistensi butirbutir yang ada dengan teknik tertentu. Variabel dikatakan reliable apabila nilai Cronbach Alpha lebih besar dari 0,60 (Sugiyono, 2010:183). Jika kita melihat daftar $\mathrm{r}$ tabel untuk banyak responden 100 orang dengan tingkat signifikan 0,05 , dapat diketahui bahwa nilai $r$ tabelnya $=0.1966$. Dapat disimpulkan berdasarkan output di atas, nilai alpha $>\mathrm{r}$ tabel atau nilai alpha $>0,60$, maka angket ini reliable atau konsisten.

\section{Uji Normalitas}

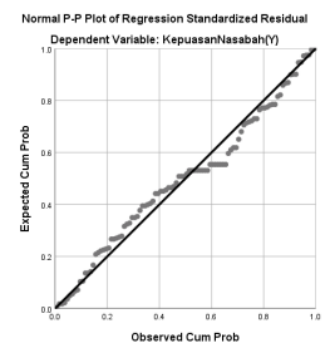

Uji normalitas dilakukan untuk mengetahui apakah data berdistribusi normal atau tidak. Dapat dilihat dari grafik di atas bahwa data menyebar di sekitar garis diagonal, maka data dikatakan terdistribusi secara normal atau tidak ada penyimpangan.

\section{Uji Linearitas}

\section{ANOVA Table}




\begin{tabular}{|c|c|c|c|c|c|c|c|}
\hline & & & $\begin{array}{c}\text { Sum of } \\
\text { Square } \\
\text { s }\end{array}$ & $\mathrm{df}$ & $\begin{array}{c}\text { Mean } \\
\text { Square }\end{array}$ & $F$ & Sig. \\
\hline \multirow{5}{*}{$\begin{array}{l}\text { Kepu } \\
\text { asan } \\
\text { Nasa } \\
\text { bah( } \\
\text { Y) * } \\
\text { Kualit } \\
\text { asPel } \\
\text { ayan } \\
\text { anCS } \\
\text { (X) }\end{array}$} & \multirow{3}{*}{$\begin{array}{l}\text { Between } \\
\text { Groups }\end{array}$} & (Combined) & 843.705 & 28 & 30.132 & 8.388 & .000 \\
\hline & & Linearity & 723.254 & 1 & 723.254 & 201.341 & .000 \\
\hline & & Deviation from Linearity & 120.451 & 27 & 4.461 & 1.242 & .232 \\
\hline & Within Groups & & 255.045 & 71 & 3.592 & & \\
\hline & Total & & $\begin{array}{r}1098.75 \\
0\end{array}$ & 99 & & & \\
\hline
\end{tabular}

Uji ini bertujuan untuk menguji apakah pada model regresi ditemukan adanya kolerasi antar variabel bebas. Dari output di atas, dapat dilihat bahwa nilai Sig.-nya adalah 0,232. Ini artinya nilai Sig. > 0,05 yang berarti bahwa ada hubungan linear yang signifikan antara variabel Kualitas Pelayanan CS (X) terhadap variabel Kepuasan Nasabah (Y) di Bank BJB KCP Cipanas.

\section{Uji Koefisien Regresi Sederhana (Uji T)}

\section{Coefficients $^{\mathrm{a}}$}

\begin{tabular}{|c|c|c|c|c|c|c|}
\hline \multirow{2}{*}{\multicolumn{2}{|c|}{ Model }} & \multicolumn{2}{|c|}{ Unstandardized Coefficients } & \multirow{2}{*}{$\begin{array}{c}\text { Standardized Coefficients } \\
\text { Beta }\end{array}$} & \multirow[b]{2}{*}{$\mathrm{t}$} & \multirow[t]{2}{*}{ Sig } \\
\hline & & $\mathrm{B}$ & Std. Error & & & \\
\hline 1 & (Constant) & .300 & 1.458 & & $\begin{array}{r}.20 \\
6\end{array}$ & $\begin{array}{r}.83 \\
7\end{array}$ \\
\hline & $\begin{array}{l}\text { KualitasPelayana } \\
\mathrm{nCS}(\mathrm{X})\end{array}$ & .326 & .024 & .811 & $\begin{array}{r}13 . \\
739\end{array}$ & $\begin{array}{r}.00 \\
0\end{array}$ \\
\hline
\end{tabular}

a. Dependent Variable: KepuasanNasabah(Y)

Persamaan regresi yang diperoleh:

$$
\mathbf{Y}=\mathbf{0 , 3}+\mathbf{0 , 3 2 6 X}
$$

Persamaan regresi linier diatas diperoleh persamaan regresi sebagai berikut:

a. Konstanta bernilai positif sebesar 0,3. Hal ini menunjukkan adanya hubungan searah antara variabel $\mathrm{X}$ dan variabel $\mathrm{Y}$, artinya apabila semua variabel bebas kualitas pelayanan Customer Service tidak berubah atau dianggap konstan (bernilai 0). Maka Y atau Kepuasan Nasabah bernilai Positif sebesar 0,3 .

b. Nilai Koefisien regresi variabel kualitas pelayanan $\left(\mathrm{X}_{1}\right)$ bernilai positif, yaitu 0.326; artinya setiap peningkatan kualitas pelayanan sebesar 1 satuan akan meningkatkan kepuasan nasabah sebesar 0,326. Dengan asumsi variabel lain bernilai tetap, nilai koefisien bernilai positif menunjukkan hubungan positif antara kualitas pelayanan dan kepuasan nasabah, sehingga 
semakin naik kualitas pelayanan Customer Sevice maka semakin meningkat pula kepuasan nasabah.

Uji T dilakukan untuk mengetahui apakah variabel X mempunyai pengaruh yang signifikan terhadap variabel Y. Dalam penelitian ini berarti, variabel kualitas pelayanan CS terhadap kepuasan nasabah di Bank BJB KCP Cipanas. Untuk melakukan uji t, maka kita harus menentukan t tabel dan t hitung terlebuh dahulu:

T tabel

$$
\begin{aligned}
& =\operatorname{TINV}(0,05 ; \mathrm{df}) \quad \rightarrow \text { diuji di Ms. Excel } \\
& =\operatorname{TINV}(0,05 ; 100-2-1) \\
& =1.984723
\end{aligned}
$$

Thitung $\quad=13.739$

Setelah diketahui nilai $\mathrm{t}$ tabel dan $\mathrm{t}$ hitung, selanjutnya kita harus menentukan hipotesis untuk menarik kesimpulan:

$\mathrm{H}_{0} \quad=$ Tidak ada pengaruh yang signifikan antara kualitas pelayanan CS (X) terhadap kepuasan nasabah (Y)

$\mathrm{H}_{1} \quad=$ Ada pengaruh yang signifikan antara kualitas pelayanan CS (X) terhadap kepuasan nasabah (Y)

Dari data di atas, maka dapat diketahui bahwa $\mathrm{t}$ hitung $>\mathrm{t}$ tabel. Dilihat dari siginifikansi nilai sig dibawah 0.05. Maka dapat disimpulkan:

Ho ditolak dan H1 diterima, artinya "ada pengaruh yang signifikan antara kualitas pelayanan CS (X) terhadap kepuasan nasabah (Y)”.

\section{E. KESIMPULAN}

Berdasarkan hasil analisis dan pembahasan yang telah dipaparkan, maka dapat diambil kesimpulannya sebagai berikut :

1. Variabel Kualitas Pelayanan Customer Service pada Bank BJB KCP Cipanas cukup tinggi. Mayoritas jawaban responden adalah menyatakan setuju bahwa kualitas pelayanan Customer Servicesesuai dengan yang diharapkan nasabah dan dinilai cukup baik oleh nasabah. Walaupun ada beberapa nasabah yang belum merasakan kualitas pelayanan Customer ServiceBank BJB KCP Cipanas dari segi kecepatan pelayanan, namun mayoritas nasabah setuju akan kualitas 
pelayanan Customer Serviceyang cukup tinggi dan memuaskan di Bank BJB KCP Cipanas. Dengan demikian, Bank BJB KCP Cipanas harus meningkatkan kualitas pelayanan, karena kepuasan dan ketidakpuasan nasabah adalah hasil penilaian nasabah terhadap apa yang diharapkannya dengan membeli dan menggunakan produk atau jasa bank. Jika nasabah merasa puas, maka nasabah akan kembali menggunakan jasa perusahaan dan menjadi pelanggan yang setia serta akan menceritakan pengalamannya tersebut kepada orang lain, bahkan memberi rekomendasi kepada orang lain untuk menggunakan jasa di perusahaan tersebut. Sebaliknya jika nasabah merasa tidak puas, maka nasabah tersebut juga akan menceritakan pelayanan yang mengecewakan tersebut kepada orang lain, sehingga akan memperburuk citra dan eksistensi perusahaan yang akan berakibat menurunnya jumlah pemakai jasa perusahaan.

2. Karakteristik responden nasabah Bank BJB KCP Cipanas sebagai berikut : untuk jenis kelamin responden nasabah Bank BJB KCP Cipanas didominasi nasabah berjenis kelamin laki-laki sebesar $35 \%$ dan berjenis kelamin perempuan sebesar sebesar $65 \%$, usia responden nasabah didominasi rentang usia 20-30 tahun sebesar 46\%, pendidikan responden nasabah didominasi yang berpendidikan Sarjana dengan persentase sebesar 37\%, dan yang terakhir pekerjaan responden nasabah didominasi mereka yang bekerja sebagai Guru yaitu sebesat $30 \%$, karyawan swasta sebesar 15\%, sedangkan untuk jumlah responden dengan pekerjaan paling sedikit adala PNS sebesar 6\%

3. Pelayanan Customer Serviceberpengaruh sighnifikan terhadap kepuasan nasabah Bank BJB KCP Cipanas. Besarnya pengaruh pelatihan tersebut adalah sebesar $65,8 \%$. Artinya bahwa setiap pelayanan yang diberikan Customer Service meningkat sebesar $1 \%$ maka akan meningkatkan kepuasan nasabah sebesar $65,8 \%$.

\section{REFERENSI}

Guspul, A. (2014). Pengaruh Kualitas Pelayanan dan Kepercayaan Terhadap Kepuasan Nasabah (Studi Kasus Pada Nasabah Kospin Jasa Cabang Wonosobo). Jurnal PPKM UNSIQ I, Vol.1(No.1), PP.40-54.

Hamdani, H. (2019). Dampak Kualitas Layanan Dan Nilai Nasabah Terhadap Kepuasan Nasabah Perbankan Syariah. Ekspansi: Jurnal Ekonomi, Keuangan, $\begin{array}{llll}\text { Perbankan Dan } & \text { Akuntansi, } & 11(1), & 129 .\end{array}$ 
https://doi.org/10.35313/ekspansi.v11i1.1329

Husaeni, Uus Ahmad. (2017). The Influence of Marketing Mix on Decision to be a Islamic Banking Customer in Cianjur Regency. IQTISHADIA. Vol.10 No. 2, pp. 105-119.

Marlius, D., \& Putriani, I. (2020). Kepuasan Nasabah PT. Bank Rakyat Indonesia Unit Tapan Cabang Painan Dilihat dari Kualitas Layanan Customer Service. Jurnal Pundi, 3(2), 111. https://doi.org/10.31575/jp.v3i2.151

Mulyaningsih, L., \& Suasana, I. (2016). Pengaruh Kualitas Layanan Dan Citra Perusahaan Terhadap Kepuasan Nasabah Pada Bank Ocbc Nisp Di Denpasar. E-Jurnal Manajemen Universitas Udayana, 5(1), 252130.

Saputra, R. Ben, \& Alwie, A. pURWANTI. (2015). Nasabah Terhadap Loyalitas Nasabah Pada Pt . Bank Riau Kepri Cabang Siak. Pengaruh Kualitas Pelayanan Dan Kepuasan Nasabah Terhadap Loyalitas Nasabah Pada Pt. Bank Kepri Cabang Siak, VII(2), 285-294.

Subagja, A. D., \& Hanifah, H. (2020). Pengaruh Kualitas Pelayanan Customer Service Terhadap Kepuasan Nasabah Pada Bank BJB Cabang Subang. IjdDemos, 1(2), 148-158. https://doi.org/10.31506/ijd.v1i2.16

Syahputra, A. B., \& Susianto, S. (2020). ANALISIS PENGARUH KUALITAS PELAYANAN DAN KINERJA CUSTOMER SERVICE TERHADAP KEPUASAN NASABAH (Studi Kasus Nasabah Bank Sumut .... ... Ekonomi Dan Bisnis, 477-486. http://e-journal.potensiutama.ac.id/ojs/index.php/FEB/article/view/781

Epin Supini SW, "Kualitatif dan Kuantitatif: Pengertian, Ciri, jenis, Cotoh", https://voi.co.id/kualitatif-dan-kuantitatif/, diunduh pada tanggal 11 November 2020, pukul 19.11 WIB. 